\title{
Changes of corneal biomechanical after femtosecond laser-assisted for cataract surgery
}

\author{
Biomecânica da córnea após laser de \\ femtosegundo na cirurgia de catarata
}

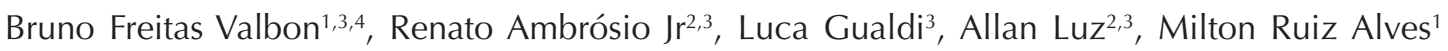

\begin{abstract}
Purpose:To evaluate the changes of corneal biomechanical after femtosecond laser - assisted cataract and to compare the parameters derived by Corvis ST between standard phacoemulsification and femtosecond laser - assisted in cataract surgery. Methods: This is a prospective study. 151 eyes of 127 patients were under went cataract surgery. 75 eyes of 65 patients were with femtosecond laserassisted (FS)(Alcon Len Sx, Aliso Viejo,USA) and 76 eyes of 62 patients with standard phacoemulsification (SP) (Alcon Infinit, Fort Worth, USA). Lens scattering was evaluated using Scheimpflug Anterior Segment Tomography, using the new software PNS. The Scheimpflug images were taken with an ultra - high - speed camera during each measurement by the Corvis ST. The deformation amplitude (DA) and other parameters (e.g., pachyapex, intraocular pressure, 1st A time, highest concavity - time, 2nd A time, 1st A Length, 2nd A Length, curvature radius highest concavity, curvature radius normal, Vin, Vout) measured by the Corvis ST were studied in groups FLS and SP before an dafter cataract surgery. Exclusion criteria: corneal disease, retinal or optic nerves disease or previous ocular surgery. This is study analyzed was Kolmogorov-Smirnov for Normality. The Wilcoxon-test and t-test were utilized to evaluate the differences between pre and day Iin FS and SP, respectively. The Mann-Whitney test was used to compare the differences of parameters derived by Corvis $S T$ - biomechanical properties between two groups (FS;SP). The p value less than 0.05 was considered statistically significant. Results: The mean age from patients of group FS was 67.6 y $( \pm 9.9)$ and the group SP was 68.4 y $( \pm 11.8)$. The mean PNS was 0.62 ( \pm 0.67$)$. In group of FS, 9 of 11 parameters derived from Corvis ST were statisticall ysignificant (ss). In group of $S P, 7$ of 11 parameters derived from Corvis ST were ss. Only the HC - time was statistically significant between two groups (FS;SP) with $p d$ "0.0387. Conclusions: The use of the femtosecond laser - assisted system for cataract surgery and standard phacoemulsification induzed changes of biomechanical properties of the cornea by Corvis ST. Only 1 of 11 parameters studied was different statistically in two groups.
\end{abstract}

Keywords: Cataract; Corneal biomechanical; Femtosecond laser; Phacoemulsification

\footnotetext{
${ }^{1}$ Post-graduate program, Faculdade de Medicina da Universidade de São Paulo, São Paulo, SP, Brazil.

2 Post-graduate program, Escola Paulista de Medicina da Universidade Federal de São Paulo, São Paulo (SP), Brazil.

${ }^{3}$ Study Group on Tomography and Biomechanics of the Cornea of Rio de Janeiro - Rio de Janeiro, RJ, Brazil.

${ }^{4}$ Faculdade de Medicina da Escola Superior de Ciências da Santa Casa de Misericórdia de Vitória, ES, Brazil.
}

The authors declare no conflicts of interest

Received for publication 31/12/2014 - Accepted for publication 28/04/2015

Rev Bras Oftalmol. 2015; 74 (5): 297-302 


\section{RESUMO}

Objetivo:Avaliar as alterações da biomecânica da córnea após o laser de femtosegundo na cirurgia de catarata e comparar os parâmetros biomecânicos derivados do Corvis ST(Oculus Corvis ST, Scheimpflug Technology; Wetzlar, Germany) entre as técnicas do laser de femtosegundo e a facoemulsificação convencional após a cirurgia de catarata. Métodos: Estudo observacional, prospectivo envolvendo 151 olhos de 127 pacientes com diagnóstico de catarata nuclear. 75 olhos de 65 pacientes foram submetidos a técnica do laser de femtosegundo (AlconLenSx, Aliso Viejo,USA) e 76 olhos de 62 pacientes por meio da facoemulsificação convencional (AlconInfinit, Fort Worth, USA). O sistema de tonometria de não-contato integrado com a câmera ultra-rápida de Scheimpflug (Oculus Corvis ST, Scheimpflug Technology; Wetzlar, Germany) foi utilizado para avaliação da biomecânica da córnea antes e após a cirurgia de catarata pelas técnicas do laser de femtosegundo e a facoemulsificação convencional.Os parâmetros biomecânicos utilizados foram: Deformidade de amplitude (DA), pressão intraocular, 1st A time, tempo de concavidade máxima, 2nd A time, 1st A Length, 2nd A Length, raio de curvatura de maior alcance, raio de curvatura normal, velocidade de entrada (Vin) e de saída (Vout).A densitometria do cristalino (scattering) através do PNS (Pentacam Nucleus Staging) foi realizada pela Tomografia de Córnea e Segmento Anterior(Pentacam ${ }^{\circledR}$ - Oculus, Wetzlar,Germany)em todos os pacientes para diagnóstico objetivo da opacidade do cristalino. Os critérios de exclusão foram: doença corneana, doenças da retina e/ou nervo óptico e cirurgia ocular prévia.O teste de Kolmogorov-Smirnov foi utilizado para avaliar a distribuição normal. O teste de Wilcoxon e o Test-T foram utilizados para avaliação entre o pré-operatório (Pré) e o primeiro dia de pós-operatório (D1) nos grupos do laser de femtosegundo (LFS) e do faco convencional (FC), respectivamente. O teste de Mann-Whitney foi realizado para avaliar as diferenças dos parâmetros biomecânicos da córnea derivados do Corvis ST entre os dois grupos (LFS; FC) após a cirurgia de catarata (D1).Foi considerado como estatisticamente significante p d" $0,05 \%$. Resultados: A média de idade dos pacientes do grupo do LFS foi de 67,6 anos $( \pm 9,9)$ e do grupo do FC foi de 68,4 anos $( \pm 11,8)$. A média do PNS entre todos os pacientes (análise objetiva do cristalino) foi de 0,62 ( $\pm 0,67$ ). No grupo do LFS, 9 dos 11 parâmetros foram estatisticamente significativos entre o Pré e D1; e no grupo do FC, 7 dos 11 parâmetros estudados foram estatisticamente significativos entre o Pré e D1. De todos os parâmetros biomecânicos derivados do Corvis ST estudados, somente o tempo de concavidade máxima da córnea (HC-time; p d" 0.0387) foi diferente entre os dois grupos (laser de femtosegundo x faco convencional) em D1. Conclusões: O laser de femtosegundo para cirurgia de catarata e a técnica de facoemulsificação convencional induziram alterações nas propriedades biomecânicas da córnea pelo Corvis ST no D1. Apenas 1 dos 11 parâmetros biomecânicos estudados foi diferente estatisticamente entre os grupos do LFS e FC.

Descritores: Catarata; Biomecânica da córnea; Laser de femtosegundo; Facoemulsificação, Scheimpflug.

\section{INTRODUCTION}

$\mathbf{C}$ ataract surgery changes the biomechanical properties of the cornea ${ }^{1}$. Although the mechanisms are not fully understood the structure of the modified cornea can influence the refractive results of the cataract surgery.

The use of energy (US_ultrasound) in conventional phacoemulsification puts the endothelial cells in danger and leads to corneal edema. ${ }^{2}$ Valbon et al. ${ }^{3}$ showed that there is an increased central corneal thickness and decreased biomechanical properties of the cornea after surgery of conventional phacoemulsification. The advance in technology with the introduction of femtosecond laser allowed a fragmentation of the core of the crest, which in turn reduces the energy levels ${ }^{4,5}$, favoring a smaller loss of endothelial cells and a faster visual recovery. ${ }^{6}$ However, there are no studies on the effects of femtosecond laser in the structural and viscoelastic properties of the cornea in the cataract surgery.

The Corvis ST (Oculus Corvis ST, Scheimpflug Technology; Wetzlar, Germany) is a new integrated non-contact tonometry system with ultra-fast Scheimpflug camera allowing a new biomechanical evaluation approach by the capture of several of dynamic images flattening of the cornea against a blow of air.

This is the first study in the world on the biomechanical properties of the cornea after the femtosecond laser for cataract surgery and comparing the viscoelastic changes of the cornea in the immediate post operative period between the techniques of conventional facoemuslifcação and the femtosecond laser.

\section{Methods}

This was a prospective observational study which evaluated 151 eyes of 127 patients with nuclear cataracts by Lens
Opacification Classification System III and by the densitometry of the crest (scattering) by PNS (Pentacam Nucleus Staging) provided by the Cornea and Anterior Segment Tomography (Pentacam ${ }^{\circledR}$ - Oculus, Wetzlar, Germany). 75 eyes of 65 patients underwent the technique of femtosecond laser (Alcon LenSx, Aliso Viejo, USA), and 76 eyes of 62 patients using the conventional phacoemulsification (Alcon Infinit, Fort Worth, USA).

The study was conducted in compliance with the standards and guidelines laid down in the Helsinki Declaration and the standards and guidelines of the Research Ethics Committee of the Medicine College of the University of São Paulo, number 278/12.

The inclusion criteria in the study were all the patients with nuclear cataracts assessed by the same doctor.

Exclusion criteria were all the patients with disease and/ or corneal opacity, retinal and/or optic nerve diseases and previous ocular surgery.

After the routine eye exam, as visual acuity with and without correction, biomicroscopy of the anterior and posterior segments, measurement of intraocular pressure and laboratory tests, all patients included in the study were assessed by the Corvis ST methods (Corneal Visualization Scheimpflug Technology; Oculus, Wetzlar, Germany) and the Cornea and Anterior Segment Tomography (Pentacam $\AA$ - Oculus, Wetzlar, Germany) before and after the cataract surgery.

Corvis ST is a new biomechanic assessment approach by capturing multiple dynamic images of cornea flattening due to a blow of air, combining no-contact tonometer data with a very high speed Scheimpflug camera. It allows us to observe, among other parameters, the range deformity (Figure 1) and swings to which the cornea is submitted. There is huge potential in research for detecting disease, assessment of cornea susceptible to ectasia, corneal behavioral observation before and after ablation in refractive surgery and the use of crosslinking. With $8 \mathrm{~mm}$ coverage in the horizontal meridian, it is able to capture the 
corneal deformation response caused by the blow of air. This imaging system allows a dynamic display of the actual deformation process during the non-contact tonometry (Figure 2). Advanced algorithms for the detection of the cornea contours are applied. The image recording begins with the cornea in natural convex shape. The blow of air forces the cornea to flatten (input stage) until it reaches the greatest concavity peak. There is an oscillation period before the output or return phase. The cornea is then subjected to a second applanation before reaching its natural shape, when there is a possible oscillation. The time

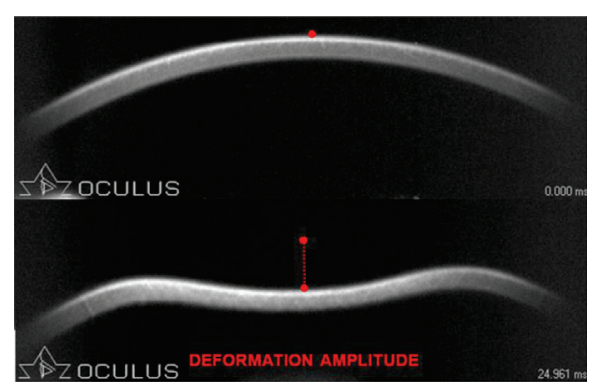

Figure 1. Scheimpflug image at the moment of deformation of corneal amplitude. and the pressure corresponding to the blow of air and the peak moment of the concavity are identified. The intraocular pressure is calculated based on the event time of the first applanation. The amplitude deformity is detected as the maximum displacement of the apex of the natural form (initial) to a maximum of concavity of the cornea. The curvature radius of the highest concavity is identified. The length of applanation and the cornea response speed are recorded during the input and output stages.

The parameters used were: amplitude deformity (AD), intraocular pressure (IOP Corvis) 1st A time, maximum concavity time (CH-time), 2nd A time, 1st A Length, 2nd A Length,

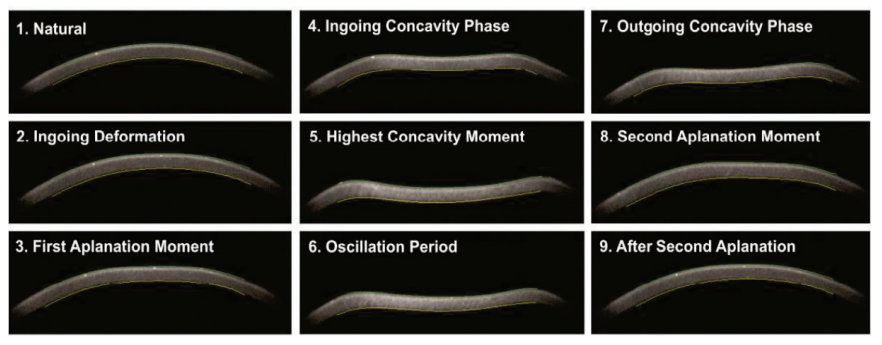

Figure 2. Dinamic view of the corneal deformation process. Stages of the examination of Corvis Scheimpflug Technology. (Courtesy Oculus).

Table 1

Biomechanical parameters derived from the Corvis ST and their definitions.

\begin{tabular}{|c|c|}
\hline Corvis ST - Clinical Parameters & Definition \\
\hline highest concavity time (ms) (HC-time) & The time from the beginning to the highest concavity of the cornea is achieved \\
\hline 2nd A-time (ms) & Time from the second corneal applanation \\
\hline 2nd A length (mm) & The length of the second corneal applanation \\
\hline Amplitude Deformity (mm) & Highest amplitude of corneal deformation \\
\hline $\begin{array}{l}\text { Curvature Radius Highest Curvature (mm) } \\
\text { (Curvature Radius } H C ; C R H C \text { ) }\end{array}$ & Central curvature radius at the moment of highest concavity \\
\hline $\begin{array}{l}\text { Curvature Radius Normal }(\mathrm{mm})(C R N) \\
\text { (Curvature Radius Normal; } C R N)\end{array}$ & Distance between the two corneal peaks in the highest concavity \\
\hline
\end{tabular}

curvature radius of higher concavity $(\mathrm{CRCH})$, average radius of curvature (CRN), input (Vin) and output (Vout) speed (Table $1)$.

The tomography of the cornea and anterior segment (Pentacam, Oculus) uses a system with a rotating chamber of $360^{\circ}$ and a photo of monochromatic light (blue LED of $475 \mathrm{~nm}$ ) having the optical principle of Scheimpflug, which gets from 25 to 100 slit images of the anterior segment in approximately 2 seconds, building three-dimensional images of the cornea and the anterior segment of the eye. After the alignment of the face the patient is instructed to look at the fixation target. The examiner observes the real-time image of the patient's eye on the computer screen, and the image is focused and centered automatically. The PNS (pentacam nucleus staging) parameter is provided by the apparatus software which sorts the densitometry of the crest from 0 to 5 (Figure 3).

The statistical analysis was performed using the Bioestat (Version 5.0 software, Belém, PA, Brazil). The KolmogorovSmirnov test was used to assess normal distribution. The Wilcoxon and test the Test- $\mathrm{T}$ were used to assess the preoperative (Pre) and the first day after surgery (D1) in the femtosecond laser group (LFS) and conventional phaco (FC), respectively. The Mann- 


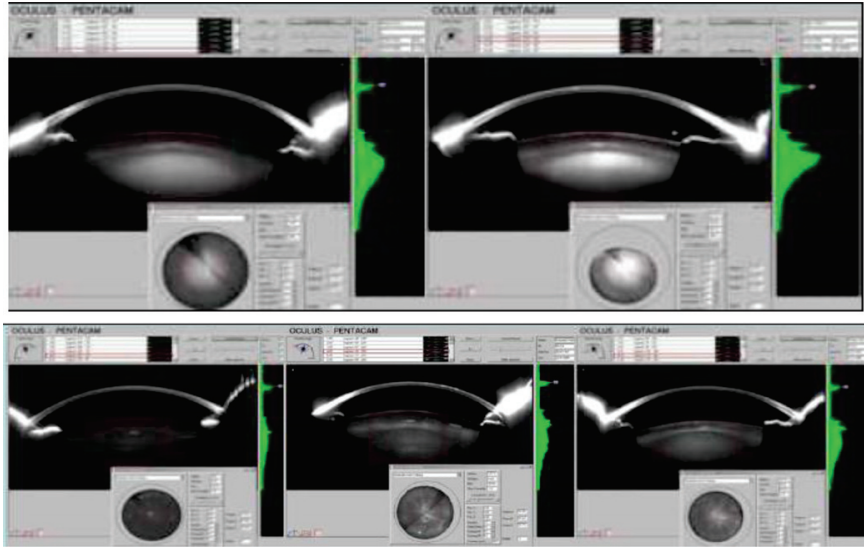

Figure 3. Scheimpflug images and the classification of densitometry of the crest (PNS).

Whitney test was performed to assess differences in the biomechanical parameters of the cornea derivative of Corvis ST between the two groups (LFS; FC) after cataract surgery (D1).

A value of $\mathrm{p} d " 0.05 \%$ was considered statistically significant.

\section{Results}

151 eyes of 127 patients divided into 2 groups were assessed. Seventy-five eyes of 65 patients underwent femtosecond laser technique, and 76 eyes of 62 patients using the conventional phacoemulsification.

The average age of the patients in the LFS group was 67.6 years $( \pm 9.9)$ and in the FC group was 68.4 years $( \pm 11.8)$. The average number of endothelial cells by specular microscopy in the LFS group was $2453.06( \pm 336.23)$ and in the the FC group was $2418.30( \pm 327.83)$. There was no statistical difference between groups $(\mathrm{p}=0.4844)$.

The average of LOCS III between NO1 and NO6 was $1.2( \pm 1.15)$.

The average PNS (pentacam nucleus staging) was $0.62( \pm$ $0.67)$.

Table 2 shows the average of all parameters derived from the Corvis ST in the preoperatively (Pre) and first day (D1) after the LFS group (Wilcoxon test, $\mathrm{p}$ value). Table 3 shows the average of all parameters derived from the Corvis ST in the pre group and in D1 in the FC group (t-test; p value). In the femtosecond laser group, 9 of 11 parameters studied were statistically significant between the Pre and the D1 groups; and in the facoconvencional group, 7 of 11 parameters studied were statistically significant between the Pre and the D1 groups as seen in Tables 2 and 3, respectively.

In Table 4, we can see the differences between the biomechanical parameters derived from Corvis ST between the two groups (LFS; FC) using the Mann-Whitney test. Of all biomechanical parameters derivated from the Corvis ST studied, only the time of maximum corneal concavity (CH-time; p d" 0.0387) (Chart 1, Figure 4) was different between the two groups (femtosecond laser $x$ conventional phaco) in D1.

\section{Discussion}

The introduction of new technologies become indispensable to the understanding and knowledge of the real qualitative changes in visual performance in the eyes with cataract. ${ }^{7}$ By increasing

Table 2

Mean and standard deviation of the parameters derived from the Corvis ST on the pre and D1 of the LFS group; Wilcoxon test used to assess the differences between Pre x D1 (LFS).

\begin{tabular}{lcccccccccccc}
\hline $\begin{array}{l}\text { Corvis ST } \\
\text { (Laser de Femtosegundo) }\end{array}$ & PIO & $\begin{array}{c}\text { 1st A } \\
\text { Time }\end{array}$ & HC Time & $\begin{array}{c}\text { 2nd A } \\
\text { Time }\end{array}$ & $\begin{array}{c}\text { 1st A } \\
\text { Length }\end{array}$ & $\begin{array}{c}\text { 2nd A } \\
\text { Length }\end{array}$ & Def.Amp. & CRHC & CRN & Vin & Vout \\
\hline PRÉ & 16.94 & 7.60 & 16.47 & 21.34 & 1.72 & 1.90 & 1.08 & 7.38 & 7.42 & 0.14 & -0.37 \\
& $(2.52)$ & $(0.34)$ & $(0.92)$ & $(0.63)$ & $(0.25)$ & $(0.58)$ & $(0.14)$ & $(1.20)$ & $(1.23)$ & $(0.03)$ & $(0.11)$ \\
\hline D1 & 22.61 & 8.32 & 16.34 & 20.6 & 31.82 & 1.94 & 0.93 & 8.48 & 8.56 & 0.12 & -0.28 \\
& $(8.02)$ & $(0.99)$ & $(0.61)$ & $(0.86)$ & $(0.20)$ & $(0.39)$ & $(0.19)$ & $(2.31)$ & $(2.32)$ & $(0.03)$ & $(0.10)$ \\
\hline Valor $\mathrm{p}$ & $\leq 0.0001$ & $\leq 0.0001$ & 0.0558 & $\leq 0.0001$ & $\leq 0.0001$ & 0.1248 & $\leq 0.0001$ & $\leq 0.0001$ & $\leq 0.0001$ & $\leq 0.0001$ & $\leq 0.0001$ \\
\hline
\end{tabular}

Table 3

Mean and standard deviation of the parameters derived from Corvis ST in the pre and D1 group of FC; T-test used to assess the differences between Pre x D1 (FC).

\begin{tabular}{|c|c|c|c|c|c|c|c|c|c|c|c|}
\hline $\begin{array}{l}\text { Corvis ST } \\
\text { (Laser de Femtosegundo) }\end{array}$ & PIO & $\begin{array}{l}\text { 1st A } \\
\text { Time }\end{array}$ & HC Time & $\begin{array}{c}\text { 2nd A } \\
\text { Time }\end{array}$ & $\begin{array}{c}\text { 1st A } \\
\text { Length }\end{array}$ & $\begin{array}{c}\text { 2nd A } \\
\text { Length }\end{array}$ & Def.Amp. & CRHC & CRN & Vin & Vout \\
\hline PRÉ & 16.87 & 7.63 & 17.40 & 22.04 & 2.02 & 1.98 & 1.10 & 8.08 & 8.10 & 0.15 & -0.35 \\
\hline D1 & $\begin{array}{l}21.71 \\
(6.50)\end{array}$ & $\begin{array}{c}8.14 \\
(0.85)\end{array}$ & $\begin{array}{l}16.56 \\
(0.49)\end{array}$ & $\begin{array}{l}20.84 \\
(0.78)\end{array}$ & $\begin{array}{l}1.85 \\
(0.21)\end{array}$ & $\begin{array}{c}1.97 \\
(0.40)\end{array}$ & $\begin{array}{l}0.95 \\
(0.16)\end{array}$ & $\begin{array}{l}8.74 \\
(2.42)\end{array}$ & $\begin{array}{c}8.71 \\
(2.17)\end{array}$ & $\begin{array}{c}0.13 \\
(0.03)\end{array}$ & $\begin{array}{l}-0.28 \\
(0.09)\end{array}$ \\
\hline
\end{tabular}


Table 4

Mann-Whitney test to assess the viscoelastic differences of the cornea on the first post-operative day in the cataract surgery between LFS and FC groups.

\begin{tabular}{lccccccccccc}
\hline $\begin{array}{l}\text { Corvis ST } \\
\text { (Mann-Whitney test) }\end{array}$ & PIO & $\begin{array}{c}\text { 1st A } \\
\text { Time }\end{array}$ & HC Time & $\begin{array}{c}\text { 2nd A } \\
\text { Time }\end{array}$ & $\begin{array}{c}\text { 1st A } \\
\text { Length }\end{array}$ & $\begin{array}{c}\text { 2nd A } \\
\text { Length }\end{array}$ & Def.Amp. & CRHC & CRN & Vin & Vout \\
\hline Valor p & 0.4190 & 0.3791 & 0.0387 & 0.1921 & 0.3256 & 0.7809 & 0.7522 & 0.5376 & 0.5961 & 0.7608 & 0.5793 \\
\hline
\end{tabular}
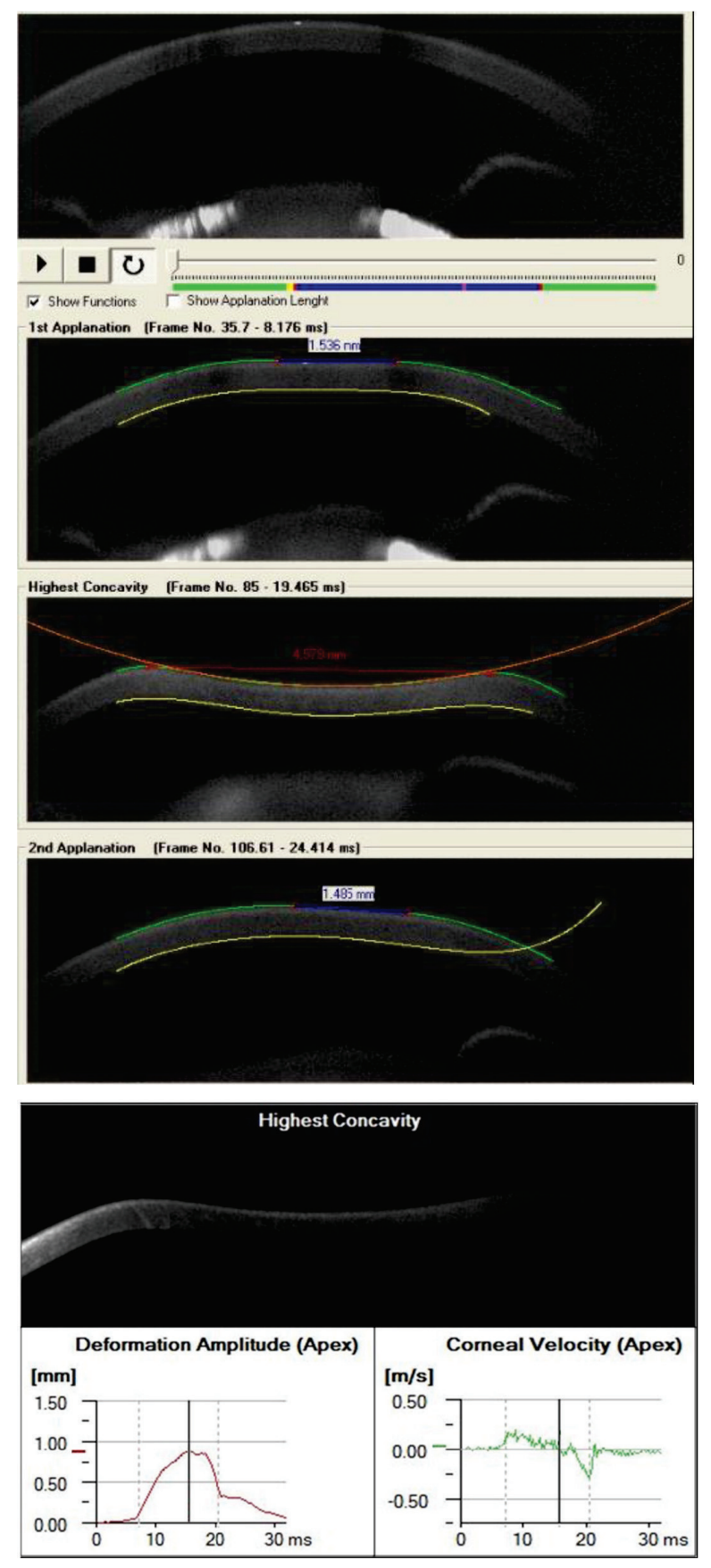

Figure 4. Scheimpflug image at the moment of maximum concavity achieved and graphics of the amplitude and displacement speed of the corneal apex. The horizontal red line shows the measurement of CH-time $(4,579 \mathrm{~mm})$.

\section{Chart 1}

We can see the box-plot of the $\mathrm{CH}$-time parameter in LFS and FC groups. This is the only biomechanical parameter studied with the statistically significant $p$ value ( $p$ d" 0,0387 ) on the first post-operative day between the two techniques (LFS; FC).

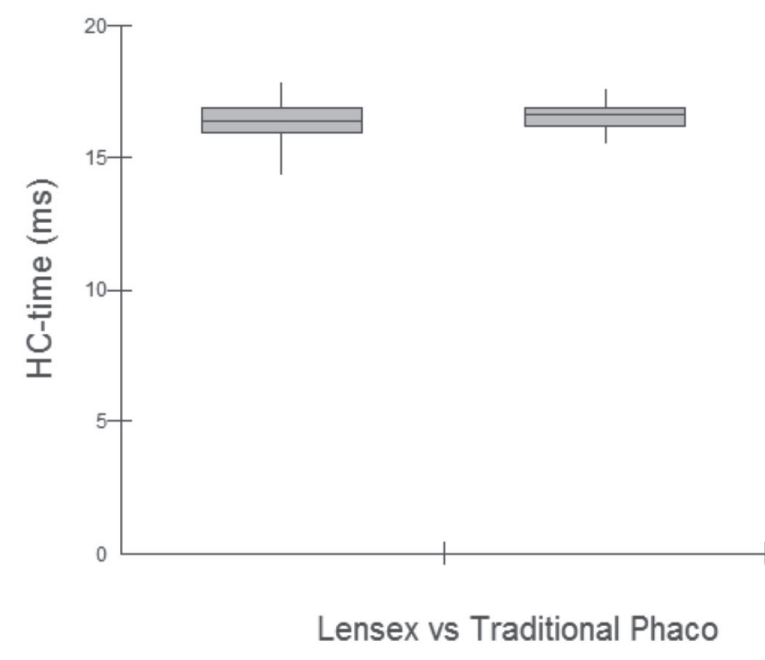

the use of premium intraocular lenses associated to an increasingly high expectation of the patients, the surgical techniques need to evolve to provide better visual performance by predictability, accuracy, and therefore avoid complications. The femtosecond laser can be an evolution as it increases the accuracy of the surgical procedure, and in turn can improve the refractive outcomes and the visual prognosis of cataract surgery. ${ }^{8}$

The cataract surgery by phacoemulsification and the implantation of intraocular lenses change the biomechanical properties of the cornea. However, the understanding of the mechanisms are not known. Many studies have reported significant reductions in the corneal hysteresis $(\mathrm{CH})$ and Corneal Resistance Factor (CRF) by ORA (Ocular Response Analyzer, Reichert Ophthalmic Instruments, Buffalo, NY, USA) after phacoemulsification. Hager et al. ${ }^{9}$ evaluated the changes of $\mathrm{CH}$ and CRF in the immediate postoperative period (D1) and found that postoperative corneal edema played an important role in reducing corneal damping capacity. Valbon et al. ${ }^{3}$ reported that post-phaco corneal edema regressed (corneal center thickness_ECC) to the normal pre operative values along with the $\mathrm{CH}$, but the $\mathrm{CRF}$ remained changed. The authors report that the CRF remaining changed can be explained by the size of the incision $(2.75 \mathrm{~mm})$ when compared to other studies that used a $2.4 \mathrm{~mm}$ incision in the paracentesis. One theory to be thought here is that there was more change in the structure of the corneal 
architecture in cases of $2.75 \mathrm{~mm}$, so there is a possible larger displacement of collagen fibers or even an incomplete healing of paracentesis. According Alió et al. ${ }^{10}$, one of the unknown mechanisms besides the corneal changes related to age, the postoperative edema which reduces the ability of the cornea to absorb and dissipate energy with a blow of air through ORA is the size and the type of incision in the cornea, which can be a confounding factor in the measurement of the viscoelasticity of the cornea. In the same study, Alio et al. ${ }^{10}$ demonstrate that the microincisions $(1.8 \mathrm{~mm})$ promote greater stability in the biomechanical properties of the cornea than the coaxial phacoemulsification surgery with paracentesis of $2.75 \mathrm{~mm}$.

The Corvis ST is a new approach to the evaluation of the cornea and with potential to drill in unprecedented ways the elasticity and viscoelasticity of the corneal tissue. We have the opportunity to observe the dynamics inspection of the cornea deformation process during non-contact tonometry with digital record of the anterior and posterior faces during the measurement. Studies have demonstrated the importance of this new approach in the diagnosis of ectasia ${ }^{11}$, assessment of the crosslinking results in the corneal collagen in ceratocone $\mathrm{e}^{12}$ and the impact of the intraocular pressure in corneal deformation in an experimental study. ${ }^{13}$

Our study is the first in the world to asess the biomechanical properties of the cornea by Corvis ST after phacoemulsification, and the first after the application of femtosecond laser in the cataract surgery. Both techniques seemed to alter the biomechanical properties of the cornea. The changes in both techniques are very similar, but the use of femtosecond laser provided changes in two more parameters derived from the most Corvis ST than the phacoemulsification technique, which are the 1 st A Length and the CRN. The first refers to the length of the first applanation of the cornea, and the second is the distance between the two cornea peaks in the maximum concavity. All parameters related to the flattening speed and deformation were altered in both techniques. We know that in preliminary studies (data not published yet) some parameters can be influenced by the corneal thickness and the intraocular pressure despite having a weak correlation.

Despite the technological advances of femtosecond laser, patients undergoing this technique had their eye more manipulated than in the phacoemulsification technique, for example, to the placement of the interface in the eyeball and the making of the arcuate incisions reaching nearly $80 \%$ of depth of the stroma in these patients. Importantly, we can not forget the learning curve in the use of femtolaser, which generates more manipulation of the eyeball at the beginning and the making of more incisions than the phacoemulsification technique. Additionally, it becomes crucial to report that on average 3 corneal incisions were made in the femtosecond laser group (2 laser and 1 manual). Therefore, we believe that these factors may have been the cause of the greater induction of biomechanical changes in the cornea using the femtosecond laser, as there was no difference between the corneal edema in the imediate post between the techniques. The only parameter statistically different when comparing both techniques is the $\mathrm{CH}$-time which means the time from the beginning of the deformation up to the maximum concavity reached by the cornea. This finding may be explained by the production of corneal incisions, which corroborates the study of Alió et al. ${ }^{10}$

We understand that the cataract surgery with the femtosecond laser can be a safe, effective and reproducible procedure. Studies show less endothelial cell loss with energy reduction compared to conventional phacoemulsification technique, having thus a faster visual recovery. ${ }^{6}$ We believe that with the learning effect in handling the interface and the making of the corneal incisions the femtosecond laser will bring great benefits in the visual performance of patients undergoing this technique by reducing the viscoelastic changes in the cornea.

In this study, we concluded that the femtosecond laser for cataract surgery and the conventional phacoemulsification technique induced changes in the biomechanical properties of the cornea by Corvis ST in the immediate postoperative period (D1). Only 1 of the 11 biomechanical parameters studied was statistically different between groups LFS and FC.

\section{ReFERENCES}

1. Kucumen RB, Yenerel NM, Gorgun E, Kulacoglu DN, Oncel B, Kohen MC, Alimgil ML. Corneal biomechanicalpropertiesand intraocular pressurechangesafterphacoemulsificationand intraocular lensimplantation. J Cataract Refract Surg. 2008; 34 (12): 2096-8.

2. Pereira ACA, Porfýrio F Jr, Freitas LL, Belfort R Jr. Ultra sound energy and endothelial cellloss with stop-and-chopand nuclear preslice phacoemulsification. J Cataract Refract Surg. 2006;32 (10):1661-6.

3. de Freitas Valbon B, Ventura MP, da Silva RS, Canedo AL, Velarde GC, Ambrósio R Jr. Central corneal thickness and biomechanical changes after clear corneal phacoemulsification. J Refract Surg. 2012;28(3): 215-9.

4. Chang JS, Chen IN, Chan WM, Ng JC, Chan VK, Law AK. Initial evaluation of a femtosecond laser system in cataract surgery. J CataractRefractSurg. 2013; 40(1): 29-36.

5. Bali SJ,Hodge C,Lawless M, Roberts TV, Sutton G. Early experience with the femtosecond laser for cataract surgery. Ophthalmology. 2012 119(5):891-899.

6. Conrad-Hengerer I, Al Juburi M, Schultz T, Hengerer FH, Dick HB. Corneal endothelial cell loss and corneal thickness in conventional compared with femtosecond laser-assisted cataract surgery: three-month follow-up. J Cataract Refract Surg. 2013;39 (9):130713.

7. Valbon BF, Alves MR, Ambrosio Jr R. Correlações entre straylight, aberrometria,opacidade e densitometria do cristalino em pacientes com catarata.RevBras Oftalmol. 2013; 72(4):244-8.

8. Chang JS, Chen IN, Chan WM, Ng JC, Chan VK, Law AK. Inicial evaluationof a femtosecond laser system in cataractsurgery. $J$ CataractRefractSurg. 2014;40(1):29-36.

9. Hager A, Loge K, Füllhas MO, Schroeder B, Grossherr M, Wiegand $\mathrm{W}$. Changes in corneal hysteresis after clear corneal cataract surgery. Am J Ophthalmol. 2007;144(3):341-6.

10. Alió JL, Agdeppa MC, Rodríguez-Prats JL, Amparo F, Piñero DP.Factorsinfluencingcornealbiomechanical changes after microincision cataract surger yand standard coaxial phacoemulsification. J CataractRefractSurg. 2010;36(6):890-7.

11. Ambrósio R, Jr., Nogueira LP, Caldas DL, et al. Corneal Biomechanical Assessment using Dynamic Ultra High-Speed Scheimpflug Technology Non-Contact Tonometry (UHS-ST NCT): Preliminary Results [Poster]. ASCRS 2011. San Diego;2011.

12. Roberts CJ. Biomechanicalandtopographicanalysis in crosslinking [Paper]. ESCRS 2012, Milan, Italy.

13. Correia FF, Ramos I, Roberts CJ, Steinmueller A, Krug M, Ambrósio $\mathrm{R}$ Jr. Impacto $\mathrm{f}$ chambre pressureand material propertiesonthedeformation response of corneal models measured by dynamic ultra-high-speed Scheimpflugimaging. Arq Bras Oftalmol. 2013;76 (5): 278-81. 